\title{
EVALUATION OF PATHOGENIC ISOLATES IN ETHIOPIA FOR THE CONTROL OF CHOCOLATE SPOT IN FABA BEAN
}

\author{
S. SAHILE, CHEMEDA FININSA, P.K. SAKHUJA and SEID AHMED ${ }^{1}$ \\ Department of Plant Science, Haramaya University P.O. Box 138, Dire Dawa, Ethiopia \\ ${ }^{1}$ International Center of Agricultural Research in the Dry Areas, P.O. Box 5466, Aleppo, Syria
}

(Received 10 July, 2009; accepted 16 November, 2009)

\begin{abstract}
Faba bean (Vicia faba L.) is one of the earliest domesticated food legumes in Ethiopia and is now cultivated on large areas in many countries. Production of the crop is, however, constrained by several disease infections including fungal diseases. The objectives of this work was to find out natural prevalence of Bacillus isolates on faba bean leaves in Amhara Regional state of Ethiopia; and to identify potential biocontrol agents for the management of chocolate spot (Botrytis fabae). Thirty eight distinct groups of isolates of Bacillus species out of a total 110 isolates obtained from 12 districts of north-west Ethiopia were found to occur on faba bean leaves. They differed in morphological and cultural characteristics. Thirty isolates of Bacillus spp. were tested for their effects on Botrytis fabae pathogen by dual culture technique on potato dextrose agar. Sixteen isolates produced 5 $\mathrm{mm}$ or higher inhibition zone and out of these isolate 43y and 56y were the most effective having inhibition zone of 8 and $7 \mathrm{~mm}$, respectively. Isolates reduced the growth of the pathogen colony in dual culture by 23-64\%. The highest reduction was caused by isolate $115 y$ (64\%), followed by $114-3 y(52 \%)$ and $29 y$ and $67 y$ (50\% each). Isolates of Bacillus were placed on actively growing colonies of $B$. fabae and were found to cause lysis of $B$. fabae mycelium. Eleven isolates caused $8 \mathrm{~mm}$ or higher lytic area of mycelium. Maximum lysis of mycelium was caused by isolates 111-1y $(16.8 \mathrm{~mm})$ and 116y $(11.3 \mathrm{~mm})$, and they were confirmed from CABI Global Plant Clinic as Bacillus and not pathogenic to plants and animals. Further evaluation of promising antagonistic isolates by the detached leaf technique showed that most of them reduced the disease development on leaves. However, the degree of disease reduction varied with cultivar. Isolates 108-2y, 20-2y, 47-2y and 36-1y proved most effective in retarding disease development on two susceptible and one tolerant cultivar and can be further explored for commercial use for management of chocolate spot disease of faba bean.
\end{abstract}

Key Words: Bacillus spp., Biocontrol, Botrytis fabae, Ethiopia

\section{RÉSUMÉ}

Le haricot faba (Vicia faba L.) est l'un des premiers domestiqués légumineuses alimentaires en Ethiopie et en est maintenant cultivé sur de grandes superficies dans de nombreux pays. La production de plant est toutefois limitée par des infections de plusieurs maladies don't les maladies fongiques. Les objectifs de ce travail étaient de découvrir la prévalence naturelle des isolats de Bacillus sur des feuilles de haricot faba dans la régions d'Amhara en Éthiopie; et d'identifier d'éventuels agentd de lutte biologique pour la gestion de taches chocolats (Botrytis fabae). Trente huit groupes distincts d'isolats d'espèces de Bacillus sur un total de 110 isolats obtenus à partir de 12 districts du Nord-Ouest de l’Éthiopie avaient été trouvés présents sur des feuilles de haricot faba. Ils différaient par les caractéristiques morphologiques et culturales. Trente isolats de Bacillus spp. avaient été testés pour leurs effets sur le pathogène Botrytis fabae par la technique de double culture sur gélose de dextrose à base de pomme de terre. Seize isolats avaient produit $5 \mathrm{~mm}$ ou bien une zone d'inhibition supérieure. De ces isolats, $43 y$ et $56 y$ étaient les plus efficaces car ayant respectivement des zones d'inhibition de 8 et $7 \mathrm{~mm}$. Les isolats réduisaient de 23-64 \% la croissance de la colonie des pathogènes sur la double culture. La réduction la plus élevée avait été causée par l’isolat 115y (64 \%), suivie de 114-3y (52 \%) et 29y et 67y (50 \% chacun). Des isolats du 
Bacillus avaient été placés sur les colonies de $B$. fabae à croissance rapide et s'étaient révélés comme étant la cause de la lyse du mycélium de $B$. fabae. Onze isolats causaient $8 \mathrm{~mm}$ ou plus de zone lytique du mycélium. La lyse maximale du mycélium avait été causée par les isolats 111-1y $(16,8 \mathrm{~mm})$ et 116y $(11,3 \mathrm{~mm})$, et ils étaient confirmés provenir de CABI Global Plant Clinic tel que Bacillus et ceux non pathogénique aux végétaux et animaux. Une évaluation prometteuse et plus approfondie des isolats antagonistes par la technique de feuilles détachées avait montré que la plupart d'entre eux réduisaient le développement de la maladie sur les feuilles. Cependant, le degré de réduction de la maladie variait avec le cultivar. Les isolats 108-2y, 20-2y, 47-2y et 36-1y s'étaient avérés plus efficaces en retardant le développement de la maladie sur deux cultivars sensibles et un seul tolérant; et peuvent être explorées davantage pour l'usage commercial dans la gestion de la maladie de tache chocolat du haricot faba.

Mots Clés: Bacillus spp., Biocontrol, Botrytis fabae, Éthiopie

\section{INTRODUCTION}

Faba bean (Vicia faba L.) is one of the earliest domesticated food legumes and is now cultivated on large areas in many countries due to its high nutritive value in terms of energy and protein contents (24-30\%). China leads in production, followed by Ethiopia, Egypt, Italy and Morocco (Bouhassan et al., 2004). The crop occupies the largest area among the pulses in Ethiopia. It is grown on 370,000 hectares with an annual production of about 450,000 tonnes (ICARDA, 2006). Even though Ethiopia is the world's second largest producer of faba bean, its share is only $6.96 \%$ of world production and $40.5 \%$ of Africa (Asfaw et al., 1994).

The production of faba bean is constrained by several yield limiting factors, of which diseases are the main factors (Samia, 2006). Chocolate disease of faba bean caused by Botrytis fabae Sard. is the most widespread and destructive disease in Ethiopia with yield reductions of up to $61 \%$ on susceptible cultivars (Dereje and Beniwal, 1987). In some countries, chocolate spot is caused by Botrytis cinerea, but in Ethiopia, only $B$. fabae is known to cause the disease. Chocolate spot initially appears as reddish brown spots on leaves, which enlarge and even merge and subsequently lead to sever premature defoliation. Under favourable conditions, it appears on stems, flowers and pods, and this directly affect seed production.

A number of management options have been developed in other countries to minimise the effects of chocolate spot on faba bean yield. These include use of resistant/tolerant varieties; use of cultural practices such as crop rotation, crop residue management, adjusting planting dates, and fungicide application (Bretag and Raynes, 2004; Hawthorne, 2004). In Ethiopia, growing of moderately resistant varieties, application of chlorothalonil or mancozeb and late planting have been recommended (Dereje, 1999; Sahile, 2008a). Large scale extensive application of chemical fungicides is neither feasible for resource poor farmers, nor environmentally desirable and safe. Moreover, the genetic base for resistance against chocolate spot is narrow in faba bean and highly resistant varieties are not available. Therefore, chemical control combined with cultural practices and moderately resistant cultivars is widely used to overcome the problem in other countries (Hawthorne, 2004). However, resistance to chemical fungicides has also been detected in $B$. cinerea and $B$. fabae (Parry, 1990; Maggie et al., 2006).

Biological control with microbes is another feasible alternative option to the use of synthetic chemicals and is now becoming a critically needed component of integrated disease management (Obagwu and Korusten, 2003; University of Sydeney, 2003). A number of fungi and bacteria are known to be very effective against soil borne diseases. Research has shown that foliar diseases can also be managed effectively through microorganisms. Among these, Bacillus spp. have been found to be very important.

Bacilli generally have simple nutritional requirements, are able to colonise dry surfaces for long period of time, they rapidly utilise many of the available nutrients and can sustain many of the environmental hazards. Several potent strains from different species of Bacillus have been tested on a wide variety of plant species for ability to control several diseases and some have 
been commercialised already. Among the different bacteria, Bacillus and Pseudomonas have been reported to have greatest potential to control Botrytis diseases (Elad and Stewart, 2004). Strain BS 153 of Bacillus has been reported to prevent chocolate spot symptoms on faba beans both in greenhouse and field studies (Sherga, 1997; Upadhyay et al., 2000).

The objectives of this work was to find out natural prevalence of Bacillus isolates on faba bean leaves in Amhara Regional State of Ethiopia; and to identify potential biocontrol agents for the management of chocolate spot.

\section{MATERIALS AND METHODS}

Bacteria sample collection and isolation. Samples of healthy looking faba bean leaves were collected in 2004 and 2005 cropping season from farmers' fields in 12 districts of Amhara Regional State in Ethiopia, located between longitude $36^{\circ}$ $40^{\circ} \mathrm{W}$ to $\mathrm{E}$, and latitudes $11^{0}-13^{\circ} 45^{\prime} \mathrm{SW}$ to $\mathrm{N}$. One $\mathrm{cm}^{2}$ pieces of tissues from the collected leaves were cut and plated on potato dextrose agar (PDA). The plates were incubated at $20-22^{\circ}$ $\mathrm{C}$ and developing young colonies of bacteria were transferred to fresh PDA plates and purified. PDA was selected as growth medium, so that their subsequent in vitro tests with $B$. fabae could be made on the same medium. Isolates grown in pure culture were coded and transferred to screwcapped culture bottles containing faba bean seed extract dextrose agar. This followed the procedure of $200 \mathrm{~g}$ of faba bean seeds added in 1 lit of distilled water and autoclaved for 30 minutes. The extract of autoclaved beans was passed through a $2 \mathrm{~mm}$ sieve, mixed with $18 \mathrm{~g}$ of agar, heated and dissolved. Then $20 \mathrm{~g}$ of dextrose was added prior to autoclaving for 20 minutes. It was cooled and poured into petri-dishes and potato dextrose agar. Isolates were stored at $4^{\circ} \mathrm{C}$ until further use.

Identification of Bacilli. All bacterial isolates were Gram stained and those having Gram positive reactions were tested for catalase reaction $(10 \%$ hydrogen peroxide was poured on the bacterial lawns to determine whether catalase was present). All catalase positive, rod-shaped and endospore forming bacteria (Bacillus) were selected for further studies. From these, human pathogenic Bacillus isolates were excluded using egg yolk mannitol bromothymol blue agar. The remaining 110 Bacillus isolates were maintained at $4{ }^{\circ} \mathrm{C}$ on slants of oxoid nutrient agar.

Growth rates Bacillus spp. isolates were compared on PDA at $21 \pm 1{ }^{\circ} \mathrm{C}$ so as to find out relatively fast growing isolates. On the basis of colony colour, margins, appearance and growth rate, the isolates were grouped into 38 groups of 110 isolates. From each group, one representative isolate was taken for antagonistic evaluation.

\section{EVALUATION OF BACILLUS ISOLATES FOR BIOCONTROL POTENTIAL}

In vitro testing of Bacillus isolates against $B$. fabae. The Bacillus isolates from the leaves were tested for antagonistic potential on PDA in $9 \mathrm{~cm}$ diameter petri-dishes, against aggressive isolate (BK-117) of B. fabae obtained from Kutaber district.

\section{Testing for antibiotic activity of Bacillus isolates.} All isolates of Bacillus spp. were tested for antibiotic production and inhibition effects on the test pathogen isolate by dual culture methods. Five mm diameter disc of five-day-old culture of the pathogen were placed near the periphery of petri-dish and a loopful of Bacillus spp. isolate was placed at the opposite periphery of the plate containing PDA (Dhingra and Sinclair, 1986). The inoculated plates were incubated along with culture plates with no antagonistic isolate at $21 \pm 1$ ${ }^{\circ} \mathrm{C}$ for 5-10 days.

The experiment was replicated three times in completely randomised design. Data on growth inhibition zone and colony diameter of pathogen and Bacillus species were recorded for each plate and inhibition of mycelial growth of the pathogen over control without Bacillus was calculated.

Testing for lytic activity of Bacillus isolates. Five millimeter discs of pathogen mycelium were placed on $15 \mathrm{ml}$ of PDA in petri-plates and incubated at $21 \pm 1^{\circ} \mathrm{C}$. After three days of mycelial growth, one loopful of the isolate of Bacillus sp grown for 48-72 hr, was placed on the actively growing colony of the pathogen and incubated at $21 \pm 1{ }^{\circ} \mathrm{C}$ for 15 days. Lysis of pathogen 
mycelium was examined periodically under a stereomicroscope (40 x magnification) and the width of lysed mycelia around the colony of the bacteria was measured. The experiment was conducted in completely randomised design and replicated three times. Culture plates having $B$. fabae but no Bacillus spp. isolate were used as control.

Isolates of Bacillus spp. that showed promising antagonistic activity under dual culture and lysis test were identified from CAB International Global Plant Clinic (UK).

Antagonistic activity in vivo. Twenty isolates which showed substantial inhibition/lysis and having higher growth rate were further evaluated for antagonistic potential by detached leaves technique (Paul et al., 1995). This was done on three faba bean cultivars namely, CS20DK (tolerant), FB-EH0013-18 (susceptible) and one local susceptible check. Leaves of the same age group of the three cultivars were taken and surface sterilised with $70 \%$ alcohol. They were placed on glass rods kept on sterile and moistened blotters in petri-plates. A conidial suspension of $B$. fabae $\left(2.5 \times 10^{5}\right.$ spores $\left.\mathrm{ml}^{-1}\right)$ was prepared according to Mohammed et al. (1994). A drop of the conidial suspension $(1 \mathrm{ml})$ was placed near the midrib proper. The petri-dishes having moist filter paper below were covered with the petri-dish lid and incubated for 24 hours at $21 \pm 1^{\circ} \mathrm{C}$.

After 24 hour, a loopful of Bacillus isolate was added to the midrib proper, where the drop of pathogen suspension was placed and incubated at $21 \pm 1^{\circ} \mathrm{C}$. A control was prepared with distilled water and another control with only pathogen suspension.

The experiment was arranged in a randomised complete block design (RCBD) with three replications. Severity rating of chocolate spot on detached leaves was assessed at 48, 72, 96 and $120 \mathrm{hr}$ after inoculation using a 1-5 scale (ICARDA, 1986).

All analyses of variance (ANOVA) on inhibition zone, lysis effect and growth rates were carried out using SAS statistical analysis package (Ver. 8). Mean separation was done using LSD test at $5 \%$ probability level.

\section{RESULTS}

Prevalence of Bacillus species on faba bean. Table 1 shows that Bacillus species were widely prevalent on faba bean leaves in north-west Ethiopia. Bacillus isolates were obtained from 110 samples of faba bean leaves from 12 districts surveyed (Fig. 1). On the basis of colony

TABLE 1. Number of effective isolates and their distribution of Bacillus species isolates from faba bean leaves in different districts of north-western Ethiopia during 2004 and 2005 cropping seasons

\begin{tabular}{|c|c|c|c|c|}
\hline Districts & $\begin{array}{l}\text { Altitude range } \\
\text { (m.a.s.l.) }\end{array}$ & $\begin{array}{l}\text { Effective } \\
\text { isolates } \\
\text { recovered }\end{array}$ & $\begin{array}{l}\text { Effective isolates code } \\
\text { recovered }\end{array}$ & $\begin{array}{l}\text { Potential Bacillus } \\
\text { isolates within each } \\
\text { district (\%) }\end{array}$ \\
\hline Yilmana-Densa & $1980-2405$ & 4 & $4 y, 6 B y, 6-2 y, 8 y$ & 10.5 \\
\hline Hulet-Eju-Ensae & $2275-2670$ & 4 & $11-2 y, 20-1 y, 20-2 y, 21 y$ & 10.5 \\
\hline Gonder-Zuria & $1969-2463$ & 3 & $28 y, 29 y, 30-3 y$ & 7.9 \\
\hline Wogera & $2650-2943$ & 5 & $34 y, 34-1 y, 34-3 y, 36-1 y, 40 b$ & 13.2 \\
\hline Debark & $2740-3053$ & 5 & 41 y, 43 y, 45 y, 47-2 y, 49y & 13.2 \\
\hline Farta & $1975-3000$ & 1 & $56 y$ & 2.6 \\
\hline Lay-Gaynt & 2794-3184 & 3 & 61 y, 64 y, 67 y, & 7.9 \\
\hline Meket & $2779-3319$ & 2 & 74 y, 76 y & 5.3 \\
\hline Gubalafto-Woldia & $1900-3033$ & - & - & 0 \\
\hline Ambasel-Tehulederae & $1908-2196$ & 1 & $108-2 y$ & 2.6 \\
\hline Kutaber & $2144-3250$ & 9 & $\begin{array}{l}111-1 \text { y, 112By, 113 y, 114-2 y, 114-3y, } \\
115 y, 116 y, 120-2 y, 126 y\end{array}$ & 23.7 \\
\hline Desei-Zuria & 2055-3138 & 1 & $134-1 y$ & 2.6 \\
\hline
\end{tabular}

- No isolate obtained 


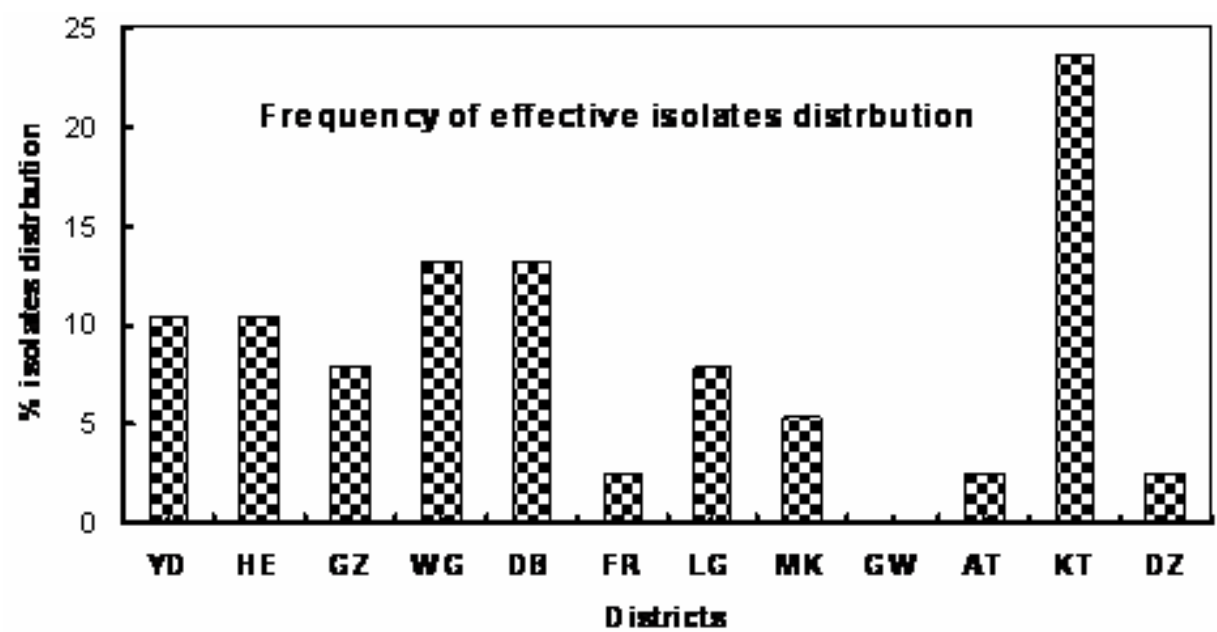

Figure 1. Percentage of effective isolates and their distribution of Bacillus spp. from faba bean leaves in different districts (YD=Yilmana-Densa, HE=Hulet-Eju-Ensae, GZ= Gonder-Zuria, WG=Wogera, DB=Debark, FR=Farta, LG=Lay-Gaynt, MK=Meket, GW= Gubalafto-Woldia, AT=Ambasel-Tehulederae, $K T=$ Kutaber, and DZ=Desei-Zuria) of northwestern Ethiopia during 2004 and 2005 cropping seasons.

characters and growth rates, they were grouped into 38 distinct groups. Maximum number (9) isolates was obtained from Kutaber district followed by Debark and Wogera (5 each), and Yilmana densa and Hulet-Eju-Ensae (4 each). No Bacillus isolate was obtained from GubalaftoWoldia, while from Farta , Ambasel-Tehulederae and Desei-Zuria only one isolate was obtained from each (Table 1).

There appeared was hardly any correlation between occurrence of Bacilli and altitude. All the 38 Bacillus isolates showed white creamy colour on both front and reverse sides of the plate. Most of the isolates started marked growth within $48 \mathrm{hr}$ of incubation and relatively fast growth of most of the isolates was observed between 72-120 hr of incubation period (Table 2). Eleven isolates out of 38 showed slight reduction in growth rate after $96 \mathrm{hr}$. Among all isolates, $115 \mathrm{y}$ from Kutaber district showed highest growth rate of $7.2 \mathrm{~mm}$ /day consistently. Isolates 20-2y, 21y, 28y, 29y, 34-3y, 40y, 49y, 67y, 114-2y, 114-3y, 120 $2 \mathrm{y}$ and 134-1y had more than $5 \mathrm{~mm}$ growth/day. Slowest growing isolates were $56 \mathrm{y}$ from Farta, and 64y from Lay Gaynt, growing $<3 \mathrm{~mm} \mathrm{day}^{-1}$. Other isolates were intermediate in growth.

Antagonistic potential of Bacillus isolates against $\boldsymbol{B}$. fabae in vitro. Significant differences
$(\mathrm{P}<0.05)$ were observed among isolates in formation of inhibition zones in dual culture (Table 3). The highest inhibition zone $(8 \mathrm{~mm})$ was observed from isolates $43 y(8 \mathrm{~mm})$ and 56y (7 mm) obtained from Debark and Farta districts, respectively. Sixteen isolates produced $5 \mathrm{~mm}$ or higher inhibition zones. The lowest inhibition zone (3 mm) was observed with isolates $8 y, 28 y$, $30-3 y, 34-3 y, 76 y, 111-1 y, 114-2 y$, and 116y, obtained from Yilmana Densa, Gondar Zuria, Wogera, Meket and Kutaber districts.

All tested isolates produced inhibition zones and also reduced growth of $B$. fabae in the dual culture (Table 3). Maximum reduction in growth rate of pathogen was observed with $115 \mathrm{y}$, which restricted the growth to $16.2 \mathrm{~mm}$ compared to 45 $\mathrm{mm}$ in the control. Sixteen isolates restricted growth to less than $25 \mathrm{~mm}$ and showed 45-64\% efficacy. In most cases, the antagonist Bacillus spp. was able to inhibit mycelia growth as well as affect the formation of conidia. In some cases, complete failure of conidial formation was observed.

Significant differences $(\mathrm{P}<0.05)$ were observed among Bacillus isolates in causing lysis of pathogen mycelium, when inoculated on actively growing colony of $B$. fabae (Table 3). The lysed areas formed by the different antagonistic isolates ranged from 5 to $16.8 \mathrm{~mm}$. 
TABLE 2. Colony growth rate of different antagonistic Bacillus isolates collected from faba bean crops of north-western Ethiopia

\begin{tabular}{|c|c|c|c|c|c|c|}
\hline \multirow[t]{2}{*}{ District } & \multirow[t]{2}{*}{ Isolate } & \multirow[t]{2}{*}{ Altitude (m. a.s.I) } & \multicolumn{4}{|c|}{ Colony growth rate (mm/day) } \\
\hline & & & $48 \mathrm{hr}$ & $72 \mathrm{hr}$ & $96 \mathrm{hr}$ & $120 \mathrm{hr}$ \\
\hline Yilmana Densa & $4 y$ & 2390 & 1.45 & 4.2 & 4.2 & 4.2 \\
\hline Yilmana Densa & 6By & 2465 & 3.8 & 3.8 & 3.8 & 3.8 \\
\hline Yilmana Densa & $6-2 y$ & 2465 & 5.45 & 5.5 & 5.5 & 5.4 \\
\hline Yilmana Densa & $8 y$ & 2386 & 4.95 & 4.9 & 4.9 & 5 \\
\hline Hulet Eju Ensae & $11-2 y$ & 2406 & 3.6 & 3.6 & 3.6 & 3.6 \\
\hline Hulet Eju Ensae & $20-1 y$ & 2597 & 4.55 & 4.5 & 4.5 & 4.6 \\
\hline Hulet Eju Ensae & $20-2 y$ & 2597 & 5.35 & 5.3 & 5.3 & 5.4 \\
\hline Hulet Eju Ensae & $21 y$ & 2576 & 5.2 & 5.2 & 5.2 & 5.2 \\
\hline Gonder Zuria & $28 y$ & 2037 & 5.45 & 5.5 & 5.5 & 5.4 \\
\hline Gonder Zuria & $29 y$ & 2075 & 5.6 & 5.6 & 5.6 & 5.6 \\
\hline Gonder Zuria & $30-3 y$ & 2241 & 3.8 & 3.8 & 3.8 & 3.8 \\
\hline Wogera & $34 y^{\prime}$ & 2064 & 5.05 & 5.1 & 5.1 & 5 \\
\hline Wogera & $34-1 y$ & 2064 & 4.65 & 4.7 & 4.7 & 4.6 \\
\hline Wogera & $34-3 y$ & 2064 & 5.2 & 5.2 & 5.2 & 5.2 \\
\hline Wogera & $36-1 y$ & 2118 & 4.25 & 4.3 & 4.3 & 4.2 \\
\hline Wogera & $40 y$ & 2689 & 5.2 & 5.2 & 5.2 & 5.2 \\
\hline Debark & $41 y$ & 2835 & 2.9 & 2.8 & 3.6 & 2.8 \\
\hline Debark & $43 y$ & 2920 & 3.6 & 3.6 & 3.6 & 3.6 \\
\hline Debark & $45 y$ & 3006 & 4.55 & 4.5 & 4.5 & 4.6 \\
\hline Debark & $47-2 y$ & 2852 & 4.2 & 4.2 & 4.2 & 4.2 \\
\hline Debark & $49 y$ & 3122 & 5.45 & 5.5 & 5.5 & 5.4 \\
\hline Farta & $56 y$ & 2851 & 2.8 & 2.8 & 2.8 & 2.8 \\
\hline Lay Gaynt & $61 y$ & 2651 & 3.4 & 3.4 & 3.4 & 3.4 \\
\hline Lay Gaynt & $64 y$ & 2173 & 2.6 & 2.6 & 2.6 & 2.6 \\
\hline Lay Gaynt & $67 y$ & 2663 & 5.6 & 5.6 & 5.6 & 5.6 \\
\hline Meket & $74 y$ & 3161 & 4.8 & 4.8 & 4.8 & 4.8 \\
\hline Meket & $76 y$ & 3249 & 4.95 & 4.9 & 4.9 & 5 \\
\hline Ambasel Tehulderae & $108-2 y$ & 2003 & 3.7 & 3.7 & 3.7 & 3.7 \\
\hline Kutaber & $111-1 y$ & 2118 & 5.05 & 5.1 & 5.1 & 5 \\
\hline Kutaber & $112 B y$ & 2131 & 4.8 & 4.8 & 4.8 & 4.8 \\
\hline Kutaber & $113 y^{\prime}$ & 2213 & 3.4 & 3.4 & 3.4 & 3.4 \\
\hline Kutaber & $114-2 y$ & 2264 & 5.6 & 5.6 & 5.6 & 5.6 \\
\hline Kutaber & $114-3 y$ & 2264 & 5.85 & 5.9 & 5.9 & 5.8 \\
\hline Kutaber & $115 y$ & 2297 & 7.2 & 7.2 & 7.2 & 7.2 \\
\hline Kutaber & $116 y$ & 2365 & 4.95 & 4.9 & 4.9 & 5 \\
\hline Kutaber & $120-2 y$ & 2505 & 5.45 & 5.5 & 5.5 & 5.4 \\
\hline Dessei Zuria & $126 y$ & 2336 & 3.4 & 3.4 & 3.4 & 3.4 \\
\hline Dessei Zuria & $134-1 y$ & 2679 & 5.45 & 5.5 & 5.5 & 5.4 \\
\hline
\end{tabular}

The highest lysed area was observed with Bacillus isolates 111-1y (16.8 mm), followed by $116 \mathrm{y}(11.3 \mathrm{~mm})$ obtained from Kutaber district, while isolates 20-1y, 21y and 34y from Hulet-EjuEensae and Wogera districts showed lowest lysis (5 mm each). The lysed area changed the colour from gray to brown around the antagonists in the petri-plates.
Evaluation of promising isolates in vivo. Isolates of Bacillus which were moderate to fast growing, exhibited substantial inhibition zones, and curtailed pathogen growth and caused lysis were further evaluated for antagonistic potential in reducing disease development on detached faba bean leaves of three cultivars. Twenty isolates were tested against virulent isolate of $B$. fabae 
TABLE 3. Performance of Bacillus species inhibition and lysis effect against Botrytis fabae on PDA

\begin{tabular}{|c|c|c|c|c|c|}
\hline \multirow[t]{2}{*}{ Isolates code } & \multicolumn{3}{|c|}{ Bacillus colony reaction } & \multirow{2}{*}{$\begin{array}{l}\text { Bacillus colony } \\
\text { growth of } 96 \mathrm{hr} \\
\text { (in } \mathrm{mm} \text { ) }\end{array}$} & \multirow{2}{*}{$\begin{array}{l}\text { Mean radial growth of } \\
\text { B. fabae at } 96 \mathrm{hr} \text { (in } \mathrm{mm} \text { ) }\end{array}$} \\
\hline & Inhibition & Lyses & Efficacy (\%) & & \\
\hline $4 y$ & 4 & 7.8 & 25.1 & 10.3 & 33.7 \\
\hline 6By & 6 & 8.5 & 33.8 & 14.2 & 29.8 \\
\hline $6-2 y$ & 4 & 9.0 & 48.6 & 20.9 & 23.1 \\
\hline $8 y$ & 3 & 6.3 & 43.8 & 18.7 & 25.3 \\
\hline $11-2 y$ & 4 & 7.8 & 32 & 13.4 & 30.6 \\
\hline $20-1 y$ & 5 & 5.0 & 40.3 & 17.1 & 26.9 \\
\hline $20-2 y$ & 6 & 7.0 & 47.4 & 20.3 & 23.7 \\
\hline $21 y$ & 4 & 5.0 & 46.2 & 19.8 & 24.2 \\
\hline $28 y$ & 3 & 7.0 & 48.6 & 20.9 & 23.1 \\
\hline $29 y$ & 4 & 7.8 & 49.8 & 21.4 & 22.6 \\
\hline $30-3 y$ & 3 & 8.5 & 33.8 & 14.2 & 29.8 \\
\hline $34 y$ & 5 & 5.0 & 45.1 & 19.3 & 24.7 \\
\hline $34-1 y$ & 5 & 6.3 & 41.5 & 17.7 & 26.3 \\
\hline $34-3 y$ & 3 & 6.5 & 46.2 & 19.8 & 24.2 \\
\hline $36-1 y$ & 4 & 7.8 & 37.9 & 16.1 & 27.9 \\
\hline $40 y$ & 4 & 6.3 & 46.2 & 19.8 & 24.2 \\
\hline $41 y$ & 5 & 7.5 & 27.1 & 11.2 & 32.8 \\
\hline $43 y$ & 8 & 7.8 & 32 & 13.4 & 30.6 \\
\hline $45 y$ & 4 & 9.5 & 40.3 & 17.1 & 26.9 \\
\hline $47-2 y$ & 5 & 8.5 & 37.3 & 15.8 & 28.2 \\
\hline $49 y$ & 4 & 7.5 & 46.2 & 20.9 & 23.1 \\
\hline $56 y$ & 7 & 7.8 & 24.9 & 10.2 & 33.8 \\
\hline $61 y$ & 6 & 7.5 & 30.2 & 12.6 & 31.4 \\
\hline $64 y$ & 5 & 7.0 & 23.1 & 9.4 & 34.6 \\
\hline $67 y$ & 6 & 7.5 & 49.8 & 21.4 & 22.6 \\
\hline $74 y$ & 4 & 8.5 & 42.7 & 18.2 & 25.8 \\
\hline $76 y$ & 3 & 7.0 & 43.8 & 18.7 & 25.3 \\
\hline $108-2 y$ & 4 & 7.5 & 32.9 & 13.8 & 30.2 \\
\hline $111-1 y$ & 3 & 16.8 & 45.1 & 19.3 & 24.7 \\
\hline 112By & 5 & 8.0 & 42.7 & 18.2 & 25.8 \\
\hline $113 y$ & 5 & 7.5 & 30.2 & 12.6 & 31.4 \\
\hline $114-2 y$ & 3 & 9.0 & 49.8 & 21.4 & 22.6 \\
\hline $114-3 y$ & 4 & 7.0 & 52.2 & 22.5 & 21.5 \\
\hline $115 y$ & 4 & 6.5 & 64 & 27.8 & 16.2 \\
\hline $116 y$ & 3 & 11.3 & 43.8 & 18.7 & 25.3 \\
\hline $120-2 y$ & 5 & 9.5 & 46.2 & 20.9 & 23.1 \\
\hline $126 y$ & 4 & 6.3 & 30.2 & 12.6 & 31.4 \\
\hline $134-1 y$ & 6 & 7.5 & 46.2 & 20.9 & 23.1 \\
\hline Mean & 4.5 & 7.7 & 40.7 & 17.7 & 26.6 \\
\hline Control & & & & & 4.5 \\
\hline LSD (5\%) & 1.2 & 1.75 & & 1.7 & \\
\hline
\end{tabular}

and significant $(\mathrm{P}<0.05)$ differences occurred between Bacillus isolates on local cultivar in reducing the disease. Twelve isolates of Bacillus reduced the chocolate spot development within 5 days of inoculation on a susceptible cultivar
EH0013-18; 11 isolates on tolerant cultivar (CS20DK); and 10 isolates on susceptible local check out of the total 20 evaluated. Out of these, isolates 41y, 112By, 30-3y and 108-2y proved more effective on EH0013-18, 61y and 6By on 


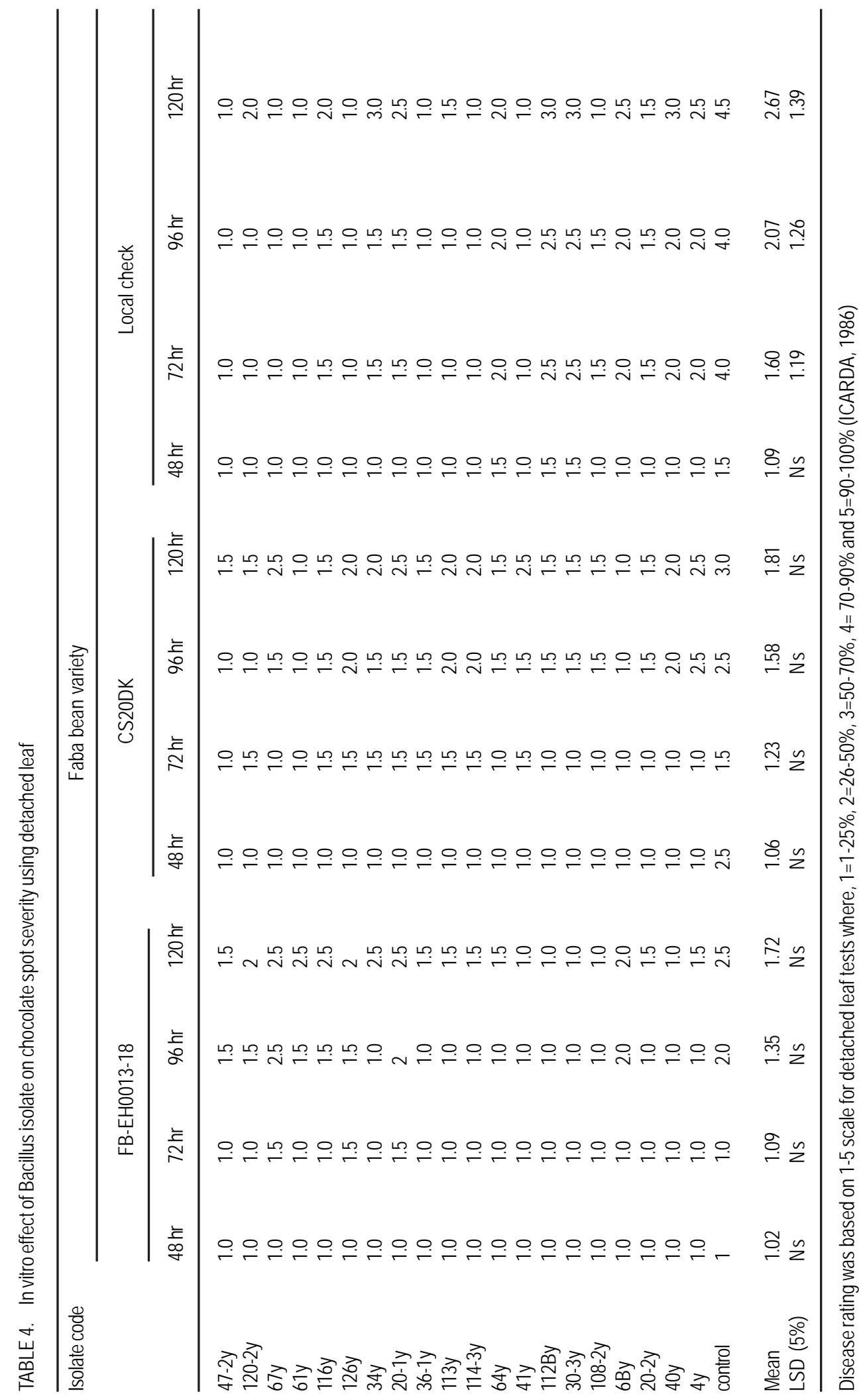


CS20DK and 47-2y, 67y, 61y, 126y 113y, 64y, 108$2 \mathrm{y}$ on local cultivar. Reduction in disease severity on the local check cultivar was more prominent and significant. Disease severity was constantly delayed on CS20DK and EH0013-18 cultivars during the observation period.

The disease severity scoring result of the cultivars showed low levels of disease pressure compared to the control. Disease initiation was not inhibited on the local susceptible check, but development after $48 \mathrm{hr}$ was reduced significantly compared to control. Isolates, isolate 108-2y, 20$2 \mathrm{y}, 47-2 \mathrm{y}$ and $36-1 \mathrm{y}$ proved most effective in reducing disease development on all the three cultivars.

\section{DISCUSSION}

This study has revealed that the biological control agents for chocolate spot of faba bean and Bacilli are natural residents of faba bean leaves in Ethiopia. Occurrence of Bacillus species on 110 leaf samples collected from 12 districts clearly indicates their wide prevalence. Differences in colony characters and growth rates showed the variability in Bacillus populations in north-west Ethiopia. Thirty eight distinct isolates were found to occur on faba bean leaves. Maximum variability was observed in Kutaber district, from where 9 distinct isolates were recovered. Bacillus species have been reported to occur on wheat and grapes also and some isolates have been found to be effective for control of foliar diseases (Kildea et al., 2008).

Laboratory studies showed the presence of significant inhibitive potential in isolates of Bacillus against $B$. fabae. Isolate $43 y$ produced largest inhibition zone under the dual culture (8 $\mathrm{mm}$ ), while isolates 111-1y and 116y caused largest lysis of pathogen mycelium, when inoculated on young colony of pathogen. Isolates 111-1y and $116 y$ were confirmed from CABI Global Plant Clinic as Bacillus and not pathogenic to plants and animals. The other 15 isolates also produced significant inhibition zones and 9 isolates had a significant degree of pathogen mycelium lysis.

Several studies have established that Bacillus isolates possess potential for controlling this serious pathogen. Gnanamanickam and Mew (1992) reported high inhibition zone by Bacillus strains 4-03 and 33 against Pyricularia oryzae, a causative of blast disease of rice. Sharma and Sharma (2008) also found that $B$. subtilus produced antifungal compounds, which caused morphological alterations in the vegetative cells and spores, and disruption and lysis of cell walls of Alternaria species causing leaf spot of mustard. Bacillus megaterium and Pseudomonas fluorescens have been found to reduce biomass of Mycoshaerella graminicola by $43 \%$ or more in dual culture (Kildea et al., 2008).

This study has revealed that the Bacillus spp. were well adapted for nutrient and better survivors against the pathogen in controlling the chocolate spot pathogen. Campbell (1994) suggested that screening must select for organisms adapted to the environment in which they are to operate. According to Sherga (1997), Bacillus isolates can be used as a biocontrol agent against Botrytis fabae and Botrytis cinarea. Antagonists can control the diseases by competing for essential nutrients, antibiosis and direct parasitism. Their secondary metabolites can cause disruption of spores and mycelium lysis. $B$. pumilus has been reported to cause lyses of germ tubes of uredospores of three cereal rusts (Morgan, 1963).

Evaluation of 20 isolates of Bacillus, which had shown significant antagonistic potential in vitro, further proved their effectiveness against the disease on detached leaves. Most of them reduced disease development, when inoculated $24 \mathrm{hr}$ after pathogen inoculation. After 5 days of inoculation, the disease was almost contained by $41 \mathrm{y}, 12 \mathrm{By}, 3-3 \mathrm{y}$ and $108-2 \mathrm{y}$ on susceptible cultivar EH0013-18; 61y and 6By on tolerant cultivar CS20DK; and 47-2y, 67y, 61y, 126y, 36$1 \mathrm{y}, 114-3 y$ 41y and 108-2y on susceptible local check. It also reflected that the isolates had different potential of controlling the disease on varieties having different levels of resistance against the disease. However, isolates 108-2y, 47$2 \mathrm{y}, 36-1 \mathrm{y}$, and 20-2y were able to control disease development equally across all the three cultivars equally.

Isolate 108-2y produced a moderate inhibition zone and caused significant lysis of mycelium in vitro. It had moderate growth rate and reduced the growth of pathogen also moderately; 
however, it proved to be the most effective on detached leaves.

Isolate 47-2y showed high inhibition zone and lysis of pathogen and proved very effective on detached leaves, but had moderate growth rate and pathogen growth reducing capacity. Isolate 20-2y produced high inhibition zones and pathogen mycelium lysis, had high growth rate and reduced growth of $B$. fabae significantly. Such observations have earlier also been reported by some workers (Sherga, 1997).

Bacillus species have a number of characteristics useful for biocontrol of plant diseases. They form endospores, which can withstand ecological stresses like high temperature and moisture stress for long periods. They are resistant to ultraviolet and gamma radiations, desiccation, lysozymes, starvation and chemical disinfectants (Thompson, 2007). They can survive well in soil as well as on leaves. $B$. subtilus has been mainly studied for biocontrol potential and occasionally B. megaterium, $B$. cerus, $B$. pumilus and $B$. polymixa have been tried (Silo-Suh et al., 1994).

Bacillus pumilus has been found to cause lyses of germ tubes of uredospores of three cereal rusts (Morgan, 1963). Bacillus has been exploited less for commercial utilisation than other bacteria for disease control, but now products are being developed. In U.K. product Serenade, (based on $B$. subtilus) is being registered for use against $B$. cinerea on strawberry (DHDC, 2008). Our studies have shown that all these four isolates have high potential of controlling chocolate spot of faba bean and can be further evaluated for commercial utilization, either alone or as a component of integrated disease management.

\section{ACKNOWLEDGMENTS}

The study was supported by International Fund for Agricultural Development (IFAD), ICARDA and Haramaya University, Ethiopia. The authors thank Haymanot Bezuneh, Haramaya University and Yenework G/medhin, Adet Agricultural Research Center, for assistance in data collection and laboratory works.

\section{REFERENCES}

Asfaw Tilaye, Beyene Demisu and Tesfaye Getachew. 1994. Genetic and breeding of field pea. First Natinal Cool-season Food Legumes Conference. Addis Ababa, Ethiopia. ICARDA/ IAR. ICARDA: Aleppo, Syria. pp. 122-137.

Bouhassan, A., Sadiki, M., and Tivoli, B., 2004. Evaluation of a collection of faba bean (Vicia faba L.) genotypes originating from the Maghreb for resistance to chocolate spot (Botrytis fabae) by assessment in the field and laboratory. Euphytica 135:55-62.

Bretag, T. W. and M. Raynes, 2004. Importance of seed coloration in faba bean (Vicia fabae) grown in southern Australia. Proceedings of the Australian Conference, Australian Society of Agronomy.

Campbell, R.1994. Biological Control of Microbial Plant Pathogens. Cambridge University Press, Cambridge. 320pp.

DHDC (Defra Horticultural Development Company). 2008. Grey mould (Botrytis cinerea), Herb Best Practice Guide. http:// www.hdc.org.uk/herbs/page.asp?id=16

Dereje Gorfu and Beniwal, S.P.S. 1987. Preliminary survey of faba bean disease in the major production areas of Ethiopia. In: Results of Research Done on Faba bean in Ethiopia, ICARDA/IAR/IFAD-Nile valley project during the cropping season. IAR, Addis Ababa, Ethiopia. pp. 78-84.

Dereje, G. 1999. Survival of Botrytis fabae Sard. Between seasons on crop debris in field soils at Holetta, Ethiopia. Phytopathologya Mediterranean 38:68-75.

Gnanamanickam, S.S. and Mew, T.W. 1992. Biological control of blastdisease of rice (Oryza sativa L.) with antagonistic bacteria and its mediation by Pseudomonas antibiotic. Ann. Phytopath. Soc. Japan 58:380-385.

Hawthorne, W. 2004. Faba bean disease management strategy for southern region. http://www.sardi.sa.gov.au/pdfserve/ fieldcrops/publications/advicefactsheets/ brochure.pdf 
ICARDA. 1986. International Center for Agricultural Research in the Dry Areas. Screening techniques for disease resistance in faba bean. Aleppo, Syria. pp. 59.

ICARDA. 2006. International Center for Agricultural Research in the Dry Areas. Technology Generations and Dissemination for Sustainable Productionof Cereals and Cool Season Legumes. Aleppo, Syria. 256pp.

Kildea, S., Ransbotyn, V., Khan, M. R., Fagan, B., Leonard, G., Mullins, E. and Doohan, F. M. 2008. Bacillus megaterum shows potential for septoria tritici blotch of wheat. Biological control 47:37-45

Maggie, E.M. H., Abd El-Rahman, S. El-Abdasi and Mikhail, M.S. 2006. Inducing resistance against faba bean chocolate spot disease. Egypt. J. Phytopathol. 34:69-79.

Mohamed, H.A., Aly, H.A. and Wadiaa, F.H. 1994. The antagonistic effect of faba bean phyloplane to Botrytis fabae Sard. Egyptian Journal of Agricultural Research 72: 645-654.

Morgan, F. L. 1963. Infection inhibition and germtube lysis of three cereal rusts by Bacillus pumilus. Phytopathology 53:1346-1348.

Obagwu, J., Korusten, L. 2003. Integrated control of citrus green and blue moulds using Bacillus subtilis in combination with sodium biocarbonate or hot water. Post harvest Biol. Technol. 28:187-194.

Parry, D. W. 1990. Plant Pathology in Agriculture. Cambridge University Press, Cambridge. pp. 181-89.

Paul, C. St. Amand and C. W. Todd 1995. Green house, Detached-leaf and Field Testing method to determine Cucumber Resistance to Gummy Stem Blight. Journal of American Society of Horticultural Science 120: 673-680.

Sahile, S., Fininsa, C., Sakhuja, P.K. and Seid, A., 2008. Effect of mixed cropping and fungicides on chocolate spot (Botrytis fabae) of faba bean (Vicia faba) in Ethiopia. Crop Protection 27:275-282.

Samia Zekaria, 2006. Production and productivity of pulse crops in Ethiopia. In: Kemal Ali (Eds.), pp. 1-5. Cool-season Food Legumes of Ethiopia. Proceedings of the workshop and forage legumes2003, Addis Ababa, Ethiopia. ICARDA/EIAR. ICARDA, Aleppo, Syria.

Sherga, B. M. 1997. Bacilus isolates as potential biocontrol agents against chocolate spot on Faba beans. Can. J. Micro-bio., 43: 915-924

Sharma, N. and Sharma, S. 2008.Control of foliar diseases of mustard by Bacillus from reclaimed soil. Microbiological Research 163:408-413.

Silo-Suh, L.A., Lethbridge, B.J., Raffel, S.J., .He, H., Clardy, J. and Handesman, J. 1994. Biological activities of two fungistatic antibiotics produced by Bacillus cereus UW85. Appl. Environ. Microbiol. 60:20232030.

Thompson, B. 2007. The role of the glycol protein in the exosporium of Bacillus https://krex.kstate.edu/dspace/bitstream/2097/354/1/ BrianThompson:Trotel-Aziz, Coudechet, M., Biagianti, S. and Aziz, A. 2008. Characterization of new bacterial biocontrol agents Acinetobater, Bacillus, Pantoea and Pseudomonas spp. mediating grape vine resistance against Botrytis cinerea. Environmental and Experimental Botany 64: 21-32.

Upadhyay, R.K., Mukerji, K.G. and Chamola, B.P. 2000. Biocontrol potential and its exploration in sustainable agriculture. vol 1 Crop disease, weeds and nematodes. Kluwer Academic publishers. pp. 1-287. 